\title{
PENINGKATAN KUALITAS HIDUP PENDERITA KUSTA DENGAN MENGGUNAKAN METODE SELF HELP GROUP (SHG)
}

\author{
Ifa Roifah \\ Stikes Bina Sehat PPNI Mojokerto \\ roifahi@yahoo.com
}

\begin{abstract}
Leprosy is one of the infectious diseases that cause a very complex problem, not only from a medical point of view. In addition there is a negative stigma from the community tends to cause the quality of life of people with leprosy decline. Quality of life is the concept of individual ability analysis to get a normal life associated with individual perceptions of goals and expectations, one of the measures to improve the quality of life of leprosy is by doing Self Help Group (SHG) therapy. This study aims to determine the quality of life in people with leprosy. The design of this research using pra experiment with pretest-posttest design approach. The samples were taken with the techniques of cluster random sampling as much as 15 respondents. Tool used WHOQOL-BREF questionnaire containing 26 questions. Patients with leprosy prior to being given Self Help Group (SHG) from 15 respondents mostly experience poor quality of life 7 people (46,7\%), leprosy patient after given Self Help Group (SHG) that from 15 respondents mostly experience quality of life is 5 people (33.3\%). The test used is using Wilcoxon Signed Rank Test. $p$ value $=0,007$ and $\alpha=0,05$ so $p<\alpha$, so Ha is accepted, it means there is influence Self Help Group therapy ( $\mathrm{SHG}$ ) to quality of life in leprosy patients in tanjungkenongo village sumberglagah kec. Pacet kab. Mojokerto. Self Help Group (SHG) is a group or peer where each member share the same physical or emotional issues or specific issues where they work together to share problems and choose what will be the focus of solving group members, helping each other in motivating to create a sense of prosperity.
\end{abstract}

\section{Keywords: Quality of Life, Leprosy, Self Help Group (SHG)}

\section{PENDAHULUAN}

Penyakit kusta merupakan salah satu penyakit menular yang menimbulkan masalah yang sangat kompleks, tidak hanya dari segi medis (mis, penyakit atau kecacatan fisik), tetapi juga meluas sampai masalah sosial dan ekonomi. Di samping itu, ada stigma negatif dari masyarakat yang mengatakan penyakit kusta merupakan penyakit yang menakutkan, bahkan ada beberapa masyarakat yang menganggap penyakit ini adalah penyakit kutukan. dampak yang ditimbulkan dari penyakit tersebut cukup parah, yaitu adanya deformitas/kecacatan yang menyebabkan perubahan bentuk tubuh (Loetfia Dwi, 2013).

Pendapat yang keliru dari masyarakat tentang penyakit kusta serta rasa takut yang berlebihan akan memperbesar persoalan sosial ekonomi penderita kusta. Pada zaman dahulu penderita kusta diasingkan dari pergaulan ke tempat terpencil. Penyakit ini juga sering disebut juga penyakit kutukan tuhan (Widoyono, 2011)

Akibatnya penderita cacat kusta (PCK) cenderung hidup menyendiri dan mengurangi kegiatan sosial dengan lingkungan sekitar, tergantung kepada orang lain, merasa tertekan dan malu untuk berobat. Dari segi ekonomi, penderita kusta cenderung mengalami keterbatasan ataupun ketidakmampuan dalam bekerja maupun mendapat diskriminasi untuk mendapatkan hak dan kesemapatan untuk mencari nafkah akibat keadaan penyakitnya sehingga kebutuhan hidup tidak dapat terpenuhi, apalagi mayoritas penderita kusta berasal dari 
kalangan ekonomi menengah ke bawah, padahal penderita kusta memerlukan perawatan lanjut sehingga memerlukan biaya perawatan. Hal-hal tersebut yang akhirnya akan mempengaruhi tingkat kualitas hidup (Juwono, 2010).

World Health Organization (WHO) mencatat jumlah penderita kusta yang dilaporkan 121 negara di 5 regional sebanyak 175.554 kasus di akhir tahun 2014 dengan 213.899 kasus baru. Indonesia tahun 2014 jumlah penderita kusta baru mencapai 17.025 jiwa, di tahun 2015 dilaporkan 17.282 kasus baru kusta dengan $84,5 \%$ kasus diantaranya merupakan tipe $\mathrm{MB}$, angka ini menempatkan indonesia sebagai negara dengan jumlah penderita kusta terbesar ke 3 di dunia setelah india dan brazil (Kemenkes, 2016). Penderita baru di Jawa Timur setiap tahun ditemukan antara 4.000-5.000 orang. Dari jumlah tersebut diatas, rata-rata $10 \%-11 \%$ ditemukan dalam kondisi cacat 2 dan 9\%-10\% adalah anak usia $<15$ th. Jumlah ini hampir hampir merata di setiap kabupaten dan kota Jawa Timur.

Kota Mojokerto tepatnya di Desa Tanjungkenongo Dusun Sumberglagah pacet, pada tahun 2016 terdapat 119 penderita kusta dengan tingkat cacat 0 sebanyak 8 orang, cacat 1 sebanyak 9 orang dan untuk cacat 2 sebanyak 102 orang. (Data kelurahan Tanjungkenongo, 2016). Tingginya angka kecacatan tingkat 2 di Desa Tanjungkenongo Dusun Sumberglagah kecamatan Pacet Mojokerto bisa diakibatkan salah satunya dari kualitas hidup yang kurang optimal.

Berdasarkan penelitian sebelumnya yang dilakukan oleh Elsya Siskawati (2014) tentang faktor yang mempengaruhi kualitas hidup orang yang pernah menderita kusta (OYPMK) didapatkan hasil rata-rata skor dukungan keluarga sebesar 70,98 dan rata-rata skor stigma terhadap QOL (Quality Of Life) sebesar 42,04 . Hal ini menunjukkan rata-rata skor kualitas hidup penderita kusta lebih rendah dibandingakn dengan kualitas hidup bukan penderita kusta.

Kusta merupakan penyakit menular yang dapat menyebabkan permasalahan yang kompleks. Masalah yang timbul bukan hanya dari sisi medis, tetapi juga aspek sosial, ekonomi, dan budaya (Widoyono, 2014). Kusta menimbulkan stigma yang besar di masyarakat yang menyebabkan timbulnya masalah psikososial (Dewi, 2015). Keterlambatan diagnosis pada penderita kusta dapat menyebabkan kecacatan permanen (Widodo, 2012). Kecacatan pada penderita kusta menyebabkan produktifitas kerja menurun. Hal ini sangat berpengaruh terhadap penurunan kualitas hidup kusta (Rahayuningsih, 2014).

WHO (2013) mendefinisikan bahwa kualitas hidup merupakan persepsi individual terhadap posisinya dalam kehidupan, dalam konteks budaya, sistem nilai dimana mereka berada dan hubungannya terhadap tujuan hidup, harapan, standar, dan lainnya yang terkait. Masalah yang mencakup kualitas hidup sangat luas dan kompleks termasuk masalah kesehatan fisik, status psikologik, tingkat kebebasan, hubungan sosial, dan lingkungan dimana mereka berada.

Informasi mengenai kualitas hidup penderita kusta diharapkan dapat menjadi dasar atau pertimbangan dalam intervensi yang direncakan terhadap penanggulanagn masalah kusta tidak hanya berfokus pada pemulihan fisik tetapi juga terhadap faktor lain yang berakibat pada penurunan kualitas hidup kusta. Psikis yang timbul karena tindakan penolakan yang terus menerus, penderita akan lebih menutup diri, malu, bahkan rasa untuk melakukan bunuh diri akan muncul karena menganggap dirinya hidup hanya sebagai hinaan masyarakat. Hal tersebut membuat penderita lebih domain pada pikiran yang maladaptif sehingga menyebabkan penurunan kualitas hidup kusta. Lalu Terapi untuk meningkatkan kualitas hidup 
penderita kusta menggunakan terapi Self Help Group (SHG).

Self Help Group atau sering disebut juga kelompok yang saling menolong, saling membantu, atau kelompok dukungan didefinisikan sebagai suatu kelompok yang menyediakan dukungan bagi setiap anggota kelompok. Anggota kelompok ini berpegangan pada pandangan bahwa orang-orang yang mengalami masalah dapat saling membantu satu sama lain dengan empati yang lebih besar dan lebih membuka diri (Ahmadi, 2007 dalam Keliat, 2009).

Terapi ini mempunyai kelebihan dan efektif untuk mengurangi masalahmasalah psikologis. Kelompok swabantu atau Self Help Group (SHG) merupakan suatu terapi dimana setiap anggota saling berbagi pengalaman tentang kesulitan dan cara mengatasinya, hal ini dilakukan untuk memberikan dukungan dan motivasi kepada individu bahwa mereka tidak sendiri dan banyak dari mereka yang bertahan dengan kondisi seperti ini. Self Help Group ini merupakan suatu bentuk terapi kelompok yang dapat dilakukan pada berbagai situasi dan kondisi (Townsed, 2007). Tujuan dari penelitian ini membuktikan pengaruh self help group (SHG) pada penderita kusta upaya untuk meningkatkan kualitas hidup pada pasien kusta

\section{METODE PENELITIAN}

Desain penelitian yang digunakan adalah pra eksperimen. Rancangan yang dipakai adalah One Group Pretes-Postest. Populasi dalam penelitian ini adalah semua warga penderita kusta RT 01, 02, 03 Dusun Sumberglagah Desa Tanjungkenongo Kecamatan Pacet Mojokerto sejumlah 119 orang penderita kusta.

Sampel yang digunakan dalam penelitian ini adalah sebagian warga penderita kusta di RT 01, 02, 03 Dusun Sumberglagah Desa Tanjungkenongo Kecamatan Pacet Mojokerto. Menurut Fraenkel dan Wallen (1993 dalam Heru
Subaris 2009), menyatakan bahwa besarnya sampel tergantung dari jenis penelitiannya. Penelitian eksperimen minimal sebesar 15 subyek. Jadi dalam penelitian ini peneliti mengambil sampel sebanyak 15 responden dari masingmasing responden di setiap RT 01, RT 02, RT 03.

Sampling dalam penelitian ini menggunakan Cluster Random Sampling yaitu pengelompokan berdasarkan wilayah atau lokasi populasi. Uji Wilcoxon Signed Ranktest digunakan dlam penelitian ini untuk analitik komparatif kategorikal berpasangan yakni untuk membandingkan 2 kategori yang berpasangan (Dahlan,2010). Uji ini untuk menguji hipotesis komparasi dua sampel berpasangan bila datanya berbentuk ordinal.

\section{HASIL PENELITIAN}

Tabel 1 Distribusi frekuensi responden berdasarkan pendidikan terakhir

\begin{tabular}{cccc}
\hline No & $\begin{array}{c}\text { Pendidikan } \\
\text { Terakhir }\end{array}$ & F & $\%$ \\
\hline 1. & Tidak Sekolah & 5 & 33,3 \\
2. & SD & 6 & 40,0 \\
3. & SMP & 3 & 20.0 \\
4. & SMA & 1 & 6,7 \\
\hline & Total & 15 & 100 \\
\hline
\end{tabular}

Tabel 1 menunjukkan bahwa sebagian besar responden dengan pendidikan terakhir SD yaitu sebanyak 6 responden $(40 \%)$.

Tabel 2 Distribusi frekuensi responden berdasarkan umur

\begin{tabular}{crcc}
\hline \multirow{2}{*}{ No } & \multirow{2}{*}{ Umur } & \multicolumn{2}{c}{ Total } \\
\cline { 3 - 4 } & & $(\mathrm{F})$ & $(\%)$ \\
\hline 1. & 15-25 Tahun & 2 & 13,3 \\
2. & 26-35 Tahun & 3 & 20,0 \\
3. & 36-45 Tahun & 10 & 66,7 \\
\hline & Total & 15 & 100 \\
\hline
\end{tabular}


Tabel 2 menunjukkan bahwa sebagian besar responden dengan umur 36-45 tahun yaitu sebanyak 10 responden $(66,7 \%)$.

Tabel 3 Distribusi frekuensi responden berdasarkan pekerjaan

\begin{tabular}{llcc}
\hline No. & \multicolumn{1}{c}{ Pekerjaan } & F & $\%$ \\
& & & \\
\hline 1. & Tidak Bekerja & 7 & 46,7 \\
2. & Wiraswasta & 1 & 6,7 \\
3. & Petani & 4 & 26,7 \\
4. & Ibu Rumah Tangga & 3 & 20,0 \\
\hline & Total & 15 & 100 \\
\hline
\end{tabular}

Tabel 3 menunjukkan bahwa sebagian besar responden dengan pekerjaan yaitu tidak bekerja sebanyak 7 responden $(46,7$ $\%)$.

Tabel 4 Distribusi frekuensi responden berdasarkan jenis kelamin

\begin{tabular}{llcc}
\hline No. & Jenis Kelamin & F & $\%$ \\
& & & \\
\hline 1. & Laki-Laki & 6 & 40,0 \\
2. & Perempuan & 9 & 60,0 \\
\hline & Total & 15 & 100 \\
\hline
\end{tabular}

Tabel 4 menunjukkan bahwa sebagian besar responden dengan jenis kelamin perempuan yaitu sebanyak 9 responden $(60 \%)$

Tabel 5 Distribusi frekuensi responden berdasarkan status pernikahan

\begin{tabular}{clcc} 
No. & Status Pernikahan & F & $\%$ \\
\hline 1. & Single & 1 & 6,7 \\
2. & Menikah & 10 & 66,7 \\
3. & Janda & 2 & 13,3 \\
4. & Duda & 2 & 13,3 \\
\hline & Total & 15 & 100 \\
\hline
\end{tabular}

Tabel 5 di atas menunjukkan bahwa sebagian besar responden dengan status pernikahan saat ini yaitu menikah sebanyak 10 responden $(66,7 \%)$.
Tabel 6 Distribusi frekuensi responden berdasarkan lama menderita kusta

\begin{tabular}{clcc}
\hline No. & $\begin{array}{c}\text { Lama Menderita } \\
\text { Kusta }\end{array}$ & F & $\%$ \\
\hline 1. & \multicolumn{1}{c}{ <10 Tahun } & 1 & 6,7 \\
2. & 10-15 Tahun & 5 & 33,3 \\
3. & 16-20 Tahun & 3 & 20,0 \\
4. & 26-30 Tahun & 2 & 13,3 \\
& Diatas 30 Tahun & 4 & 26,7 \\
\hline & Total & 15 & 100 \\
\hline
\end{tabular}

Tabel 6 menunjukkan bahwa sebagian besar responden berdasarkan lama menderita kusta yaitu 10-15 tahun sebanyak 5 responden $(33,3 \%)$.

Tabel 7 Distribusi frekuensi responden berdasarkan riwayat penyakit

\begin{tabular}{llcc}
\hline No. & $\begin{array}{c}\text { Riwayat Penyakit } \\
\text { Kusta Dalam } \\
\text { Keluarga }\end{array}$ & F & $\%$ \\
\hline 1. & Ada & 9 & 60,0 \\
2. & Tidak Ada & 6 & 40,0 \\
\hline & Total & 15 & 100 \\
\hline
\end{tabular}

Tabel 7 menunjukkan bahwa sebagian besar responden berdasarkan riwayat penyakit kusta dalam keluarga yaitu sebanyak 9 responden (60\%).

Perubahan sebelum dan setelah dilakukan intervensi; sebelum diberikan self help group (SHG) terdapat kualitas hidup buruk pada penderita kusta 7 orang $(46,7 \%)$ dan sesudah diberikan SHG 1 orang mengalami kualitas hidup buruk $(6,7 \%)$. dan setelah diberi self help group (SHG) kualitas hidup baik 5 orang $(33,3 \%)$. Sebelum diberikan self help group (SHG) penderita kusta tidak ada yang mengalami kualitas hidup baik dan setelah diberikan self help group (SHG) 4 orang $(26,7 \%)$ mengalami kualitas hidup sangat baik.

Hasil uji statistic Wilcoxon Signed Ranks Test merupakan $\mathrm{p}$ value sebesar 0,007 yang artinya nilai pvalue $<0,05$ maka $\mathrm{H}_{0}$ ditolak dan $\mathrm{H}_{1}$ diterima yang artinya ada pengaruh terapi self help 
group (SHG) terhadap kualitas hidup pada penderita kusta di desa Tanjungkenongo Dusun Sumberglagah Pacet Mojokerto.

\section{PEMBAHASAN}

1. Kualitas Hidup pada penderita Kusta sebelum diberikan self help group (SHG).

Hasil kualitas hidup penderita kusta sebelum diberikan self help group (SHG) bahwa dari 15 responden sebagian besar mengalami kualitas hidup buruk 7 orang $(46,7 \%)$, kualitas sedang 4 orang $(26,7$ $\%)$, kualitas hidup baik 4 orang $(26,7 \%)$.

Terjadinya kualitas hidup buruk pada penderita kusta karena kondisi penderita kusta merasa dikucilkan oleh masyarakat dalam sebuah kelompok-kelompok minoritas sehingga hal tersebut membentuk kualitas hidup yang buruk. Dan 4 responden yang kualitas hidupnya baik merupakan responden dengan dukungan lingkungan dan keluarga yang baik, meskipun kondisi penderita kusta merasa tidak disukai oleh masyarakat namun jika lingkungan sekitar dan terutama keluarga memberikan dukungan maka kualitas hidup dari penderita kusta akan membaik

Kualitas hidup dipengaruhi oleh kesehatan fisik, psikologi, hubungan sosial mereka dan dengan lingkungan sekitarnya. Kualitas hidup merupakan indikator tidak hanya seberapa baik fungsi individu dalam kehidupan sehari-hari, tetapi juga bagaimana persepsi individu dari status kesehatan mempengaruhi sikap hidup atau kualitas hidup (Bello \& Bello, 2013 dalam Disa Novianti,dkk 2015). Faktor yang mempengaruhi kualitas hidup kusta antara lain pendidikan terakhir, umur, pekerjaan, jenis kelamin, lama menderita musta, riwayat penyakit kusta dalam keluarga. Dari faktor pendidikan terakhir didapatkan sebagian besar responden pendidikan terakhir SD yaitu 6 orang (40,0\%). Lama mengeyam pendidikan dalam tahun berhubungan dengan penurunan Kualitas Hidup Penderita Kusta (Tsutsumi, 2007).

Dari faktor umur didapatkan sebagian besar responden berusia 36-45 tahun yaitu 10 orang $(66,7 \%)$. Merupakan dewasa akhir atau memasuki masa prelansia. Berdasarkan penelitian yang dilakukan Riff dan Singer, individu dewasa mengekspresikan kesejahteraan yang lebih tinggi pada usia dewasa. Penelitian yang dilakukan pada responden tua menemukan adanya kontribusi dari faktor usia terhadap kualitas hidup subjektif individu yang disebabkan karena individu pada masa usia tua sudah melewati masa untuk melakukan perubahan dalam hidupnya sehingga mereka cenderung mengevaluasi hidupnya dengan lebih positif dibandingkan masa mudanya.

Dari faktor pekerjaan didapatkan sebagian besar responden tidak bekerja yaitu 7 orang (46,7\%). Moons, Marquet, Budst dan de Geest (2004) mengatakan bahwa terdapat perbedaan kualitas hidup antara penduduk yang berstatus pelajar, penduduk yang bekerja, penduduk yang tidak bekerja (atau sedang mencari pekerjaan), dan penduduk yang tidak mampu bekerja (atau memiliki disabilitas tertentu). Wahl, Rustoen, Hanestad, Lerdal dan Moum (2004) menemukan bahwa status pekerjaan berhubungan dengan kualitas hidup baik pada pria atau wanita.

Dari faktor jenis kelamin didapatkan sebagian besar responden berjenis kelamin perempuan yaitu 9 orang $(60,0 \%)$. Menurut Joseph dan Rao (2009) dalam penelitiannya menemukan bahwa keseluruhan ranah penilaian kualitas hidup pasien kusta laki-laki maupun perempuan lebih rendah. Pasien kusta laki-laki dengan cacat memiliki nilai kualitas hidup yang lebih rendah dibandingkan dengan pasien yang tidak cacat. Walaupun pasien kusta perempuan dengan cacat juga memiliki nilai kualitas hidup yang lebih renda, namun tidak bermakna secara statistik. Bila dibandingkan antara perempuan dan laki-laki, nilai kualitas 
hidup perempuan lebih tinggi pada seluruh ranah penilaian. Hal ini dikarenakan perempuan lebih siap menerima penyakitnya, sejalan dengan peranan perempuan di india yang di anggap nomor dua.

Dari faktor riwayat penyakit kusta dalam keluarga didapatkan sebagian besar ada riwayat penyakit kusta dalam keluarga yaitu 9 orang $(60 \%)$. Menurut klasifikasi oleh Euis Rahayuningsih (2012) tentang analisis kualitas hidup penderita kusta, dari penelitian bebererapa peneliti, dia menyebutkan faktor-faktor yang memepengaruhi kualitas hidup penderita kusta adalah adanya riwayat penyakit kusta dalam keluarga, karena dengan adanya riwayat kusta dalam keluarga dapat berkontribusi terhadap pengalaman penerimaan keluarga terhadap anggota keluarga dengan penyakit serupa.

Artinya, dengan adanya penerimaan dari keluarga dengan adanya anggota keluarga dengan memiliki penyakit yang sama membuat penderita merasa lebih tenang karena tidak hanya karena adanya anggota keluarga lain yang memiliki penyakit sama saja tapi penderita merasa memiliki dukungan dari keluarga dengan diterimanya dirinya didalam keluarga tersebut sehingga walaupun secara kesehatan fisik individu tersebut merasa kurang puas akan tetapi dengan adanya penerimaan keluarga membuat kesehatan mental, psikologi, dan kepercayaan pribadi mereka lebih baik.

2. Kualitas Hidup pada penderita Kusta setelah diberikan self help group (SHG)

Kualitas hidup penderita kusta sesudah diberikan Self Help Group (SHG) bahwa dari 15 responden sebagian besar mengalami kualitas hidup sedang 5 orang $(33,3 \%)$, kualitas baik 5 orang $(33,3 \%)$, kualitas hidup sangat baik 4 orang $(26,7 \%)$.

Terjadinya kualitas hidup baik pada penderita kusta karena kondisi penderita kusta merasa diterima dan diperhatikan oleh masyarakat dan tidak merasa dikelompok-kelompok sehingga hal tersebut membentuk kualitas hidup yang baik. Dan 4 responden yang kualitas hidupnya sangat baik merupakan responden dengan dukungan lingkungan dan keluarga yang baik, meskipun kondisi penderita kusta merasa tidak disukai oleh masyarakat namun jika lingkungan sekitar dan terutama keluarga memberikan dukungan maka kualitas hidup dari penderita kusta akan membaik. Pada 4 responden dengan kualitas hidup sedang adalah responden yang ibu rumah tangga, sedangkan pendidikan SMP dan berusia 36-45 tahun faktor inilah yang dapat membentuk kualitas hidup responden dalam kategori sedang.

Pada hasil penelitian setelah diberikan SHG maka terdapat sebagian besar mengalami Kualitas Hidup sedang 5 orang $(33,3 \%)$, hal ini karena responden telah menerima perlakuan dari peneliti terkait dengan kelompok swabantu yang bertujuan untuk menghilangkan keminderan pada responden sehingga dapat membantu responden memperbaiki kualitas hidupnya. Kualitas hidup baik 5 orang $(33,3 \%)$, kualitas hidup baik yang terdapat pada 5 responden karena telah memahami terkait dengan perawatan diri yang diberikan peneliti melalui kelompok swabantu. Kualitas hidup sangat baik 4 orang $(26,7 \%)$. Pada responden yang kualitas hidupnya sangat baik karena saat diberikan SHG mereka telah meresponnya dengan baik dan berusaha untuk merealisasikanya dalam kehidupan sehari - hari.

Kualitas hidup dipengaruhi oleh kesehatan fisik, psikologi, hubungan social mereka dan dengan lingkungan sekitarnya. Kualitas hidup merupakan indikator tidak hanya seberapa baik fungsi individu dalam kehidupan sehari-hari, tetapi juga bagaimana persepsi individu dari status kesehatan mempengaruhi sikap hidup atau kualitas hidup (Bello \& Bello, 2013 dalam Disa Novianti,dkk 2015). 
Faktor yang mempengaruhi Kualitas Hidup Kusta antara lain Pendidikan Terakhir, Umur, Pekerjaan, Jenis Kelamin, Lama Menderita Kusta, Riwayat Penyakit Kusta dalam Keluarga. Dari faktor Pendidikan Terakhir tabel 4.1 didapatkan sebagian besar responden pendidikan terakhir SD yaitu 6 orang $(40,0 \%)$. Lama mengeyam pendidikan dalam tahun berhubungan dengan penurunan Kualitas Hidup Penderita Kusta (Tsutsumi, 2007).

Perhatian yang diberikan masyarakat terhadap penderita kusta mampu memberikan motivasi untuk meningkatkan kualitas hidupnya. Penerimaan dari keluarga dengan adanya anggota keluarga dengan memiliki penyakit yang sama membuat penderita merasa lebih tenang karena tidak hanya karena adanya anggota keluarga lain yang memiliki penyakit sama saja tapi penderita merasa memiliki dukungan dari keluarga dengan diterimanya dirinya didalam keluarga tersebut sehingga walaupun secara kesehatan fisik individu tersebut merasa kurang puas akan tetapi dengan adanya penerimaan keluarga membuat kesehatan mental, psikologi, dan kepercayaan pribadi mereka lebih baik dan bahkan sangat baik.

3. Pengaruh self help group (SHG) terhadap Kualitas Hidup pada penderita kusta

Kualitas hidup sebelum dan sesudah diberikan self help group didapatkan bahwa sebelum diberikan self help group (SHG) terdapat 7 orang $(46,7 \%)$ dan setelah diberi self help group (SHG) terdapat 5 orang $(33,3)$ yang mengalami kualtas sedang. Hasil uji statistic Wilcoxon Signed Ranks Test merupakan $p$ value sebesar 0,007 yang artinya nilai $p$ value $<0,05$ maka $\mathrm{H}_{0}$ ditolak artinya ada pengaruh terapi self help group (SHG) terhadap kualitas hidup pada penderita kusta di Desa Tanjungkenongo Dusun Sumberglagah Pacet Mojokerto.
Tujuan Self Help Group dalam kelompok adalah memberikan support terhadap sesama anggota dan membuat penyelesaian masalah secara lebih baik dengan cara berbagi perasaan dan pengalaman, belajar tentnag penyakit dan memberikan asuhan, memberikan kesempatan caregiver untuk berbicara tentang permasalahan dan memilih apa yang akan dilakukan, saling mendengarkan satu sama lain, membantu sesama anggota kelompok untuk berbagi ide-ide dan informasi serta memberikan support, meningkatkan kepedulian antar sesama anggota sehingga tercapainya perasaan aman dan sejahtera, mengeotahui bahwa mereka tidak sendiri. Supprt group juga memberikan kesempatan kepada caregiver untuk berbagi perasaan, masalah, ide-ide dan informasi dengan yang lain yang mempunyai masalah yang sama. Selain itu juga memberikan kepuasan karena dapat berbagai dan membantu satu dengan yang lainnya (Utarmi, 2008). Pada pertemuan pertama yang paling bnayak berperan adalah fasilitator, karena anggota belum memahami prinsip pelaksanaan self-help group (Keliat, 2008).

Kualitas hidup (quality of life) digunakana dalam bidang pelayanan kesehatan untuk menganalisis emosional seseorang, faktor sosial, dan kemampuan untuk memenuhi tuntutan kegiatan dalam kehidupan secara normal dan dampak sakit dapat berpotensi untuk menurunkan kualitas hidup terkait kesehatan (Brooks \& Anderson dalam Nursalam, 2016). Pengertian kualitas hidup terkait kesehatan juga sangat bervariasi antar banyak peneliti. Definisi menurut WHO, sehat bukan hanya terbebas dari penyakit, akan tetapi juga berarti sehat secara fisik, mental, maupun sosail. Seseorang yang sehat akan mempunyai kualitas hidup yang baik, begitu pula kualitas hidup yang baik tentu saja akan menunjang kesehatan (Nursalam, 2016).

Meskipun terdapat responden yang mengalami kualitas hidup buruk setelah 
diberikan SHG namun pada hasil penelitian ini juga terdapat peningkatan kualitas hidup setelah diberikan SHG. Pada responden yang kualitas hidupnya semakin buruk terdapat pada responden yang kurang meresponden kegiatan SHG dan mempunyai tingkat pendidikan yang rendah serta tidak bekerja. Hal ini merupakan faktor yang sangat mempengaruhi kualitas hidup seseorang meskipun telah diberikan perlakuan.

\section{SIMPULAN}

Ada pengaruh pemberian terapi self help group ( $S H G$ ) terhadap kualitas hidup pada penderita kusta di Desa Tanjung Kenongo Pacet Mojokerto, dengan hasil yang diperoleh dari uji statistic wilcoxon signed ranks test hasil yang diperoleh didapatkan hasil maka $\mathrm{p}$ value $0,007<0,05$ sehingga Ho ditolak yang artinya ada pengaruh terapi Self Help Group (SHG) terhadap kualitas hidup pada penderita kusta. Karena Self Help Group (SHG) merupakan suatu kelompok atau peer dimana tiap anggota saling berbagi masalah baik fisik maupun emosional atau issue tertentu dimana mereka saling bekerjasama untuk berbagi permasalahan dan memilih apa yang akan dijadikan fokus pemecahan anggota kelompok, saling membantu dalam memotivasi sehingga tercipta perasaaan sejahtera.

\section{SARAN}

1. Penerapan self help group dalam aplikasi program puskesmas berbasis pemberdayaan masyarakat khususnya kelompok penderita kusta.

2. Diharapkan dapat dikembangakn metode kombinasi self help group dan peer group 1 dalam meningkatkan kualitas hidup penderita kusta.

DAFTAR PUSTAKA

Dahlan, 2009. Statistik Untuk Kedokteran dan Kesehatan. Jakarta: Salemba Medika.
Dahlan, M. S, 2010. Membuat Proposal Penelitian Bidang Kedokteran dan Kesehatan. Jakarta: CV Sagung Seto.

Heru Subaris Kasjono, Yasril, 2009. Teknik Sampling Untuk Peneleitian Kesehatan. Yogyakarta: Graha Ilmu. Juwono, Juniarto, A.Z., 2010 Bilogi Sel. Jakarta: Penerbit Buku Kedokteran EGC.

Kaur \& Van Brankel. 2007. Dehabilitattion of Leprosy Affected People A Study On Leprosy Affected Beggars. $\quad$ www.leprahealthaction diakses pada tanggal 30 Desember 2016.

Keliat, B. A. 2009. Modul Kelompok Swabantu (Self- Help Group). Jakarta: FIK UI.

Kemenkes RI, 2007. Profil Kesehatan Indonesia. Jakarta: Departemen Kesehatan Rik

Kemenkes RI, 2016. Kusta, Infodatin dan Informasi Kesehatan Kementerian RI. www.datakemenkeskusta.co.id diakses pada tanggal 23 Desember 2016.

Tsutsumi, A., Izutsu, T., Akramul Islam MD., Maksuda., A., Kato, H., \& Wakai, S. 2007. The Quality of Life, Mental Health and Perceived Stigma of Leprosy Patients in Bangladesh.Social Science \& Medicine.

Utami, T.W, 2008. Pengaruh Self-Help Groups Terhadap Kemampuan Keluarga Dalam Merawat Klien Gangguan Jiwa Di Kelurahan Sindang Barang Bogor Tahun 2008. Hasil Tesis Fakultas Keperawatan Universitas Indonesia diakses 27 Desember 2016.

Widoyono, M. 2011. Penyakit Tropis Epidemiologi, Penularan, Pencegahan \& Pemberantasannya. Ciracas, Jakarta: Erlangga. 